\title{
Fish Stock Assessment and Potential Yield of a Reservoir in Benin City, Nigeria
}

\author{
Wangboje, O. M. \\ Department of Aquaculture and Fisheries Management, \\ University of Benin, \\ P.M.B. 1154, Benin City, Nigeria.
}

Email: oiseoje.wangboje@uniben.edu

\begin{abstract}
Fish stock assessments of aquatic ecosystems are relevant against the backdrop of over exploitation, fish species extinction and the inadequate management of aquatic resources especially in developing countries such as Nigeria. The study specifically examined the fish stock assessment and the potential fish yield of the Ikpoba reservoir in Benin City, Nigeria. A total of 903 fishes were captured from the reservoir with individual abundance ranging from 18 (1.99 \%) for Epiplatys sexfasciatus to 286 (31.67 \%) for Synodontis clarias. A total of 15 fish species belonging to 8 families were identified while the dominant fish species were S. clarias, Hemichromis fasciatus and Marcusenius psittacus. A total of 11 fish species were identified as rare in this study. The Ekiuwa station of the reservoir was the richest species-wise $(d=6.45)$ while the Midpoint station had the greatest general diversity of fish species $(H=$ 1.42). There was a more even spread and distribution of fish species at the Midpoint station $(E=1.00)$ while the commonest fish species were most frequent at the Okhoro station $(C=1.62)$. In this study, the Condition Factor ranged from 1.00 for M. psittacus to 5.78 for Gnathonemus abadii. The potential fish yield index of the reservoir was low due to a low nutrient content and ranged from 17.7 in the dry months to 23.13 in the wet months. It was advocated that the Ikpoba reservoir must be continuously monitored in order to ensure that fish species composition and diversity do not reach critical limits.
\end{abstract}

Keywords: Fish, Stock assessment, Reservoir, Nigeria

\section{INTRODUCTION}

Fish is an important staple food which contributes to the livelihood and food security of millions of people around the world. Its flesh is a source of top quality protein and for many in emerging economies it represents a significant proportion of the animal protein in their diet. Fish can also be seen as a renewable natural source provided that aquatic bodies are not overfished (Ames et al., 1991). It has been reported that 32\% of global fish stocks are overexploited or depleted and as much as $90 \%$ of large species have been captured in the last half-century with global fin and shell fish consumption peaking at about $83 \mathrm{~kg}$ per person per year (Walsh, 2011). In the last three decades capture fisheries production has come under intense exploitation and global landings have reached a plateau of about 90 million metric tonnes (Choo \& Williams, 2003). Nigeria is blessed with an estimated inland water mass of 
about 283, 298. 47 hectares capable of producing over 2.5 million metric tonnes of fish annually (Orji \& Onyejiaka, 1990) while the nation has been recognised as a large fish consumer with a total consumption of more than 1.3 million metric tonnes per year (Abdullah, 2011). In Nigeria, it has been reported that fishery yields from inland aquatic bodies have been hampered by factors such as environmental degradation, high fishing pressure from increasing human populations, poor fishery data and unclear property rights (Khan et al., 2004). The numerous freshwater bodies of Nigeria with over 270 fish species are considered to be the richest in fish diversity in West Africa (Idodo-Umeh, 2003). These fishes comprise Nilo-Sudanian, Guinean and Zairean fishes (Olaosebikan \& Raji, 2013). Fish species of several inland aquatic bodies in Nigeria have been studied, identified and recorded (Adesulu \& Sydenham, 2007). Fish stock assessments of aquatic ecosystems are relevant against the backdrop of over exploitation, fish species extinction and the inadequate management of aquatic resources especially in developing countries such as Nigeria. Furthermore, knowledge of species composition, diversity, emperical evidence of fish populations and abundance in aquatic bodies is a vital key to the sustainable management of aquatic resources (Ibim \& Igbani, 2013). It is on this premise that the present study was undertaken on the Ikpoba reservoir located in Benin City, Southern Nigeria which serves as an important source of drinking water and fisheries resources. From available literature, the most recent study on fish composition and diversity of the reservoir was carried out over a decade ago (Fufeyin, 1994). The present study is thus specifically geared towards investigating the fish species composition of the reservoir, their diversity, relative abundance and the potential fish yield of the investigated ecosystem against the backdrop of anthropogenic activities in the vicinity of the study area which could have a negative impact on the investigated indices. Furthermore, this study is expected to provide up to date data on the dynamics of the fish composition and diversity in the reservoir.

\section{METHODOLOGY}

\section{The study area}

The study area is located between Latitude $6.5^{\circ} \mathrm{N}$ and Longitude $5.8^{\circ} \mathrm{E}$ in Benin City, Nigeria and falls within the Tropical rain forest belt. The Ikpoba river is dendrite in the upper reaches and its head waters originate from the Ishan Plateau. The river was impounded in 1977, forming the Ikpoba reservoir. The reservoir at full capacity is $3.25 \mathrm{~km}$ long and $0.6 \mathrm{~km}$ wide and has a mean depth of $4 \mathrm{~m}$ with a storage capacity of the Dam being 1.5 million $\mathrm{m}^{3}$ (Wangboje, 2013). Rainfall is typically bi-modal peaking in July and September with a short break in August. The geomorphologic characteristics of the study area have been described in detail by Asuen \& Oronsaye (1990).

\section{Sampling technique}

Fish samples were captured with the assistance of artisanal fishermen who deployed baited hooks, cast nets and local fish traps made up of cane and wire, from four stations established within the reservoir namely, Okhoro station, Midpoint station, Low lift pump station and Ekiuwa station. The Okhoro and Ekiuwa stations are adjacent to the Okhoro and Ekiuwa communities of the City respectively while the Midpoint station is approximately equidistant between the Okhoro and Low lift pump stations. It is at the Low lift pump station that water is pumped out for treatment by the State Urban Water Board. Captured fish samples were placed in labeled black polythene bags and thereafter moved in an ice chest to the main laboratory of the Faculty of Agriculture, University of Benin, within 24 hours for further studies. Water samples for total dissolved solids determination, were also collected from the aforementioned stations in 1 litre polythene bottles with screw caps approximately $30 \mathrm{~cm}$ 
below the water surface. The bottles were rinsed with 5\% concentrated nitric acid and thereafter washed out with distilled water and dried prior to use (Ademoroti, 1996). The campaign spanned from January to November 2007.

\section{Laboratory protocol}

In the laboratory, fish specimens were identified using taxonomic keys (Holden \& Reed, 1972; Olaosebikan \& Raji, 1998, Adesulu \& Sydenham, 2007). Fundamental morphometric measurements (in $\mathrm{cm}$ ) of total length, standard length and body depth were measured using a measuring board and meter rule while wet weights of whole specimens were recorded to the nearest $0.01 \mathrm{~g}$ using a Mettler ${ }^{\circledR}$ top loading electronic balance (Model PE 360). Water samples were analysed for Total dissolved solids $(\mathrm{Mg} / \mathrm{l})$ using standard procedures (American Public Health Association, 1998).

\section{Estimation of potential fish yield}

The potential fish yield was estimated using the Morpho-edaphic Index (MEI) according to (Horne \& Goldman, 1994).

$$
\text { MEI = Total dissolved solids in water }\left(\frac{\mathrm{Mg}}{\mathrm{l}}\right) / \text { Mean depth (M) of reservoir }
$$

Fish species abundance score

According to Ibim \& Igbani (2013), the fish species abundance score was assigned as follows. $1-50=\operatorname{Rare}(\mathrm{R}), 51-100=$ Few $(\mathrm{F}), 101-200=$ Common $(\mathrm{C}), 201-400=$ Abundant $(\mathrm{A})$

Fish species diversity indices

The species diversity indices applied, include the under listed according to Chapman, (1996).

i. $\quad$ Margalef's index $(\mathrm{d})=\mathrm{S}-1 / \ln (\mathrm{N})$

Where $S=$ Total number of species, $N=$ Total number of individuals,

$\ln =$ Natural logarithm. The index indicates species richness at stations.

ii. Shannon-Wiener diversity index $(\mathrm{H})=\mathrm{N} \log \mathrm{N}-\Sigma$ fi $\log$ fi/N

Where $\mathrm{N}=$ Total number of individuals, $\mathrm{fi}=$ individual abundance of species.

The index evaluates general diversity taking into account the abundance of each species.

iii. $\quad$ Evenness index $(E)=H / \log S$; Where $S=$ Total number of species, $H=$ ShannonWiener diversity index. The index measures the evenness of distribution of species amongst stations.

iv. Simpson's dominance index $(\mathrm{C})=\Sigma(\mathrm{ni} / \mathrm{N})^{2}, \mathrm{ni}=$ individual abundance of species, $\mathrm{N}=$ Total number of species. The index measures the degree of dominance of a species.

\section{Condition factor for fish}

The Condition factor expresses the fatness, wellbeing, and relative robustness of a fish. It is believed that a heavier fish of a given length is in better condition than a lighter fish of the same length (Nikolsky, 1963). Condition factor $=100^{*} \mathrm{~W} / \mathrm{L}^{3}$. Where $\mathrm{W}=$ weight of fish $(\mathrm{g}), \mathrm{L}=$ length of fish $(\mathrm{cm})$.

\section{Statistical methods}

Fish data were presented with simple descriptive statistics such as means and percentages. Analysis of Variance (ANOVA) was applied to determine significant differences between mean values of total dissolved solids at $5 \%$ level of significance. Significant means were separated with the New Duncan Multiple Range Test. The Student t-test statistic was used to separate means between wet and dry months. 


\section{Results}

A total of 15 fish species belonging to 8 families were identified during the study period (Table 1). In the overall, a total of 903 fishes were captured with individual abundance ranging from $18(1.99 \%)$ in the case of E. sexfasciatus to 286 (31.67\%) in the case of S. clarias. S. clarias was abundant while $H$. fasciatus and M. psittacus were common with M. deliciosus being few. The other 11 identified species were rare (Table 2). The Margalef's index (d) ranged from 2.23 at the Midpoint station to 6.45 at the Ekiuwa station while the Shannon-Weiner index $(\mathrm{H})$ ranged from 0.75 at the Okhoro station to 1.42 at the Midpoint station (Table 3). The Evenness index (E) ranged from 0.63 at the Okhoro station to 1.00 at the Midpoint station while the Simpson's index (C) ranged from 0.05 at the Midpoint station to 1.60 at the Okhoro station. In this study, the Condition Factor ranged from 1.00 for M. psittacus to 5.78 for G. abadii (Table 4). The mean Total dissolved solids in water ranged from $48.80 \mathrm{mg} / 1$ in the month of April to $125.50 \mathrm{mg} / 1$ in the month of June. There were significant differences $(\mathrm{P}<0.05)$ in the mean Total dissolved solids between the sampled months (Table 5). The potential fish yield of the reservoir ranged from 17.7 in the dry months to 23.13 in the wet months (Table 6). The longest total length (18.9 $\mathrm{cm})$ and longest standard length $(16.5 \mathrm{~cm})$ were both recorded for M. electricus while the widest body depth $(5.2 \mathrm{~cm})$ was recorded for E. sexfasciatus (Table 7). At the Okhoro station, the heaviest fish weight of $65.43 \mathrm{~g}$ was recorded for $C$. nigrodigitatus while at the Midpoint station the heaviest fish weight of $81.63 \mathrm{~g}$ was recorded for $M$. macropthalmus (Table 8). At the Low lift pump station the heaviest fish weight of $103.63 \mathrm{~g}$ was recorded for $C$. gariepinus while at the Ekiuwa station the heaviest fish weight of $76.23 \mathrm{~g}$ was recorded for M. macropthalmus.

Table 1: Complete checklist of fish species captured from the Ikpoba reservoir

\begin{tabular}{ll}
\hline S/N & FAMILY/GENUS/SPECIES of captured fish \\
\hline 1. & FAMILY: NOTOPTERIDAE \\
& GENUS: Xenomystus \\
& SPECIES: Xenomystus nigri (GUNTHER, 1868) \\
2. & FAMILY: MORMYRIDAE \\
& GENUS: Mormyrus \\
& SPECIES: Mormyrus macrophthalmus (GUNTHER, 1866) \\
3. & FAMILY: MORMYRIDAE \\
& GENUS: Marcusenius \\
& SPECIES: Marcusenius psittacus (BOULENGER, 1897) \\
4. & FAMILY: MORMYRIDAE \\
& GENUS: Mormyrops \\
& SPECIES: Mormyrops deliciosus (LEACH, 1818) \\
5. & FAMILY: MORMYRIDAE \\
& GENUS: Gnathonemus \\
& SPECIES: Gnathonemus abadii (BUOLENGER, 1901) \\
6. & FAMILY: BAGRIDAE \\
& GENUS: Chrysichthys \\
& SPECIES: Chrysichthys nigrodigitatus (LACEPEDE, 1803) \\
7. & FAMILY:MALAPTERURIDAE \\
& GENUS: Malapterurus \\
& SPECIES: Malapterurus electricus. (GMELI, 1789) \\
&
\end{tabular}


SPECIES: Synodontis clarias (LINNAEUS. 1766)

9. FAMILY: MOCHOKIDAE

GENUS: Synodontis

SPECIES: Synodontis eupterus (BOULENGER, 1901)

10. FAMILY: MOCHOKIDAE

GENUS: Synodontis

SPECIES: Synodontis filamentosus (BOULENGER, 1901)

11. FAMILY: NOTOPTERIDAE

GENUS: Papyrocranus

SPECIES: Papyrocranus afer (GUNTHER, 1868)

12. FAMILY: CLARIDAE

GENUS: Clarias

SPECIES: Clarias gariepinus (BURCHELL, 1822)

13. FAMILY: CYPRINODONTIDAE

GENUS: Epiplatys

SPECIES: Epiplatys sexfasciatus (GILL, 1862)

14. FAMILY: CICHLIDAE

GENUS: Chromidotilapia

SPECIES: Chromidotilapia taeniatus (BOULENGER, 1901)

15. FAMILY: CICHLIDAE

GENUS: Hemichromis

SPECIES: Hemichromis fasciatus (PETERS, 1857)

Table 2: Individual abundance and percent composition of fish species in Ikpoba reservoir

\begin{tabular}{lll}
\hline Fish & $\begin{array}{c}\text { Individual } \\
\text { abundance } \\
\text { of species }\end{array}$ & $\begin{array}{l}\% \\
\text { Composition }\end{array}$ \\
\hline S.clarias & $286(\mathrm{~A})$ & 31.67 \\
H.fasciatus & $127(\mathrm{C})$ & 14.06 \\
M.psittacus & $111(\mathrm{C})$ & 12.32 \\
M.deliciosus & $60(\mathrm{~F})$ & 6.66 \\
C.nigrodigitatus & $47(\mathrm{R})$ & 5.22 \\
M.macrophthalmus & $39(\mathrm{R})$ & 4.33 \\
P.afer & $37(\mathrm{R})$ & 4.11 \\
X.nigri & $35(\mathrm{R})$ & 3.88 \\
S.eupterus & $27(\mathrm{R})$ & 2.99 \\
C.taeniatus & $25(\mathrm{R})$ & 2.77 \\
M.electricus & $24(\mathrm{R})$ & 2.66 \\
C.gariepinus & $24(\mathrm{R})$ & 2.66 \\
G.abadii & $23(\mathrm{R})$ & 2.55 \\
S.filamentosus & $20(\mathrm{R})$ & 2.22 \\
E.sexfasciatus & $18(\mathrm{R})$ & 1.99 \\
& $\sum 903$ & $\sum 100 \%$ \\
\hline Where: & & \\
\hline
\end{tabular}

Where: 1-50 = Rare(R), 51- 100 = Few (F), $101-200=$ Common (C), 201- $400=$ Abundant (A) 
Table 3: Species diversity indices for fish in the Ikpoba reservoir

\begin{tabular}{|c|c|c|c|c|}
\hline Index & Okhoro station & Midpoint station & $\begin{array}{l}\text { Low lift pump } \\
\text { station }\end{array}$ & Ekiuwa station \\
\hline Margalef's(d) & 2.46 & 2.23 & 6.03 & 6.45 \\
\hline $\begin{array}{l}\text { Shannon- } \\
\text { Weiner(H) }\end{array}$ & 0.75 & 1.42 & 1.07 & 0.97 \\
\hline Evenness(E) & 0.63 & 1.00 & 0.91 & 0.82 \\
\hline Simpson's(C) & 1.62 & 0.05 & 0.10 & 0.13 \\
\hline
\end{tabular}

Table 4: Condition factors (CF) for fish species from the Ikpoba reservoir

\begin{tabular}{lllll}
\hline S/N & $\begin{array}{l}\text { Fish } \\
\text { Species }\end{array}$ & $\begin{array}{l}\text { Mean weight } \\
(\mathrm{g})\end{array}$ & $\begin{array}{l}\text { Mean length } \\
(\mathrm{cm})\end{array}$ & CF \\
\hline 1. & S. clarias & 26.52 & 11.45 & 1.76 \\
2. & H. fasciatus & 38.91 & 13.25 & 1.67 \\
3. & M. psittacus & 46.11 & 16.65 & 1.00 \\
4. & M. deliciousus & 41.63 & 12.85 & 1.96 \\
5. & C. nigrodigitatus & 55.89 & 16.95 & 1.15 \\
6. & M. macropthalmus & 63.38 & 16.15 & 1.50 \\
7. & P. afer & & & \\
8. & X. nigri & 53.39 & 12.60 & 2.66 \\
9. & S. eupterus & 44.42 & 13.55 & 1.78 \\
10. & C. taeniatus & 54.46 & 11.15 & 3.92 \\
11. & M. electricus & 51.05 & 12.85 & 2.40 \\
12. & C. gariepinus & 72.21 & 17.45 & 1.36 \\
13. & G. abadii & 73.15 & 11.30 & 5.07 \\
14. & S. filamentosus & 44.34 & 9.15 & 5.78 \\
15. & E. sexfasciatus & 51.65 & 10.80 & 4.10 \\
\hline
\end{tabular}

Table 5: Mean values of total dissolved solids in water from Ikpoba reservoir

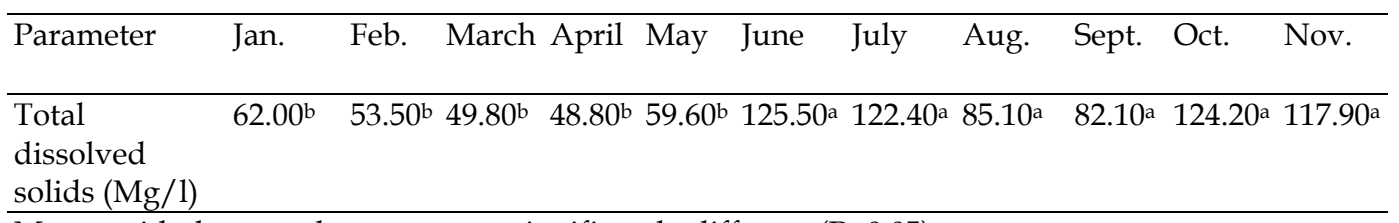

Means with the same letters are not significantly different $(\mathrm{P}>0.05)$

Table 6: Potential fish yield of the Ikpoba reservoir

\begin{tabular}{llll}
\hline Season & $\begin{array}{l}\text { Mean Total } \\
\text { Dissolved } \\
\text { Solids }(\mathrm{Mg} / \mathrm{l})\end{array}$ & $\begin{array}{l}\text { Mean Depth } \\
\text { of Reservoir }(\mathrm{M})\end{array}$ & $\begin{array}{l}\text { Potential Fish } \\
\text { Yield }\end{array}$ \\
\hline *Dry months & $70.80^{\mathrm{a}}$ & 4 & 17.70 \\
${ }^{* * \text { Wet months }}$ & $92.53^{\mathrm{a}}$ & 4 & 23.13 \\
\hline
\end{tabular}

Means with the same letters are not significantly different $(\mathrm{P}>0.05)$

*Dry months are January, February, March and November

** Wet months are April to October. 
Table 7: Range of morphometric measurements $(\mathrm{cm})$ of fish species from Ikpoba reservoir

\begin{tabular}{llll}
\hline Fishes species & Total length & Standard length & Body depth \\
\hline X. Nigri & $12.8-14.3$ & - & $2.3-3.1$ \\
M. macrophthalmus & $14.8-17.5$ & $13.3-15.0$ & $2.8-3.3$ \\
M. psittacus & $15.5-17.8$ & $14.3-16.0$ & $3.1-3.3$ \\
M. delisiousus & $9.9-15.8$ & $9.3-12.8$ & $1.9-3.4$ \\
G. abadii & $7.0-11.3$ & $5.3-8.3$ & $2.5-4.3$ \\
C. nigrodigitatus & $15.5-18.4$ & $14.2-15.7$ & $2.9-3.4$ \\
M. electricus & $16.0-18.9$ & $14.6-16.5$ & $3.4-3.6$ \\
S. clarias & $9.2-13.7$ & $7.9-11.5$ & $1.4-2.5$ \\
S. eupterus & $8.4-13.9$ & $6.8-11.9$ & $1.5-3.2$ \\
S. filamentosus & $7.8-13.8$ & $6.3-12.0$ & $1.3-3.0$ \\
P. after & $9.6-15.6$ & - & $1.8-3.2$ \\
C.gariepinus & $9.0-13.6$ & $7.8-11.2$ & $1.3-2.3$ \\
E. sexfasciatus & $7.0-17.0$ & $5.5-13.5$ & $2.0-5.2$ \\
C. taeniatus & $11.9-13.8$ & $8.7-10.6$ & $2.8-3.6$ \\
H. fasciatus & $12.2-14.3$ & $9.4-10.8$ & $3.6-4.3$ \\
\hline
\end{tabular}

Table 8: Range of wet weights (g) of fish species from Ikpoba reservoir

\begin{tabular}{lllll}
\hline Fishes species & $\begin{array}{l}\text { Okhoro } \\
\text { Station }\end{array}$ & Midpoint station & $\begin{array}{l}\text { Low lift } \\
\text { station }\end{array}$ & $\begin{array}{l}\text { pump } \\
\text { Ekiuwa } \\
\text { Station }\end{array}$ \\
\hline X.nigri & $38.47-53.68$ & $40.27-52.44$ & $50.37-62.31$ & $44.53-59.26$ \\
M.macrophthalmus & $44.24-56.93$ & $62.72-81.63$ & $80.23-82.52$ & $73.44-76.23$ \\
M. psittacus & $32.36-43.71$ & $52.33-64.42$ & $56.53-62.44$ & $48.26-59.86$ \\
M. delisiousus & $34.64-46.18$ & $34.91-38.43$ & $45.77-52.36$ & $42.45-48.63$ \\
G. abadii & $46.23-50.26$ & $38.43-46.25$ & $43.84-49.28$ & $38.93-44.52$ \\
C. nigrodigitatus & $45.15-65.43$ & $47.38-52.43$ & $42.55-91.27$ & $52.37-69.24$ \\
M. electricus & $42.50-46.25$ & $50.15-75.20$ & $60.70-101.92$ & $43.76-48.23$ \\
S.clarias & $24.12-28.93$ & $43.27-78.60$ & $56.44-63.75$ & $38.42-43.57$ \\
S. eupterus & $53.42-64.30$ & $44.63-56.44$ & $48.63-53.71$ & $49.32-52.66$ \\
S. filamentosus & $46.77-52.25$ & $38.94-64.36$ & $39.92-62.39$ & $42.37-60.30$ \\
P.after & $38.36-43.47$ & $46.15-74.22$ & $53.86-68.42$ & $45.23-49.29$ \\
C.gariepinus & $43.47-45.93$ & $42.66-55.37$ & $90.26-103.64$ & $56.25-72.74$ \\
E. sexfasciatus & $38.35-46.84$ & $44.78-62.16$ & $60.34-65.73$ & $63.52-73.71$ \\
C. taeniatus & $40.36-51.36$ & $36.43-41.30$ & $38.41-72.36$ & $38.53-65.67$ \\
H. fasciatus & $25.43-38.95$ & $42.73-52.45$ & $39.26-45.36$ & $50.15-52.40$ \\
\hline
\end{tabular}

\section{DISCUSSION}

In this study, a total of 903 fishes were captured from the Ikpoba reservoir as against a total of 448 fishes collected by Fufeyin (1994) also for the Ikpoba reservoir, while a total of 15 species belonging to 8 families were identified in this study, 29 species and 18 families were identified by Fufeyin (1994), for the same water body. Seven (7) fish species were common to both studies. This observation gives an indication that these seven fish species are typically to be found in the reservoir. The fish species identified in this study that were not encountered in the study by Fufeyin (1994) were X. nigri (Notopteridae), M. macrophthalmus (Mormyridae), M. psittacus (Mormyridae), S. clarias (Mochokidae), S. filamentosus (Mochokidae) and C. taeniatus (Cichlidae). This obsevation may be attributed to changes in environmental conditions over time and it gives an insight into the dynamics of fish species composition in the reservoir. In this study, S. clarias was abundant while $H$. fasciatus and M. psittacus were common. The dominant fish species in this study were S. clarias, H. fasciatus and M. psittacus as they accounted for over $10 \%$ of the fish collection (Tetsola, 1988). The dominant fish species in the study by Fufeyin (1994) were Hemichromis elongatus, Chromidotilapia guentheri, Chrysichthys nigrodigitatus and Hemichromis bimaculatus. This finding clearly shows that in both 
studies the Cichlids (H. fasciatus, $H$. elongatus and $H$. bimaculatus) are typically dominant species in the reservoir. This may be attributed to the prolific rate of reproduction exhibited by these species on one hand and probably to a successful adaptation to the ecological conditions in the reservoir on the other hand. In another study by Fufeyin (1998), the dominant fish species identified in the reservoir were Chromidotilapia guentheri and Tilapia mariae which are both Cichlids. Ibim and Igbani (2013), identified 36 fish species belonging to 29 families in the Lower New Calabar river, Rivers State, Nigeria and reported that the Cichlids were the dominant fish species in that ecosystem. Oguzie (1999), identified the wide distribution of Oreochromis niloticus (another Cichlid) in the Ikpoba reservoir, which was however not encountered in this study. The Condition factors, revealed that the fish species were generally well conditioned. This may have been as a result of abundant natural food items for the fish species in the reservoir and conceivably conducive water quality conditions. The heaviest fish weight and longest fish length were recorded for S. clarias and M. electricus respectively. These two fish species are cat fishes which naturally have voracious appetites and therefore tend to easily attain large sizes. Ogbeibu \& Ezeunara (2002), identified 28 fish species belonging to 14 families, in Ikpoba river. The fish collection was dominated by the Families Cichlidae and Bagridae. The fish species that were common with this study were $X$. nigri, C. nigrodigitatus, M. electricus, C. gariepinus, C. taeniatus and H. fasciatus. Tawari-Fufeyin \& Ekaye (2007), examined fish species diversity as indicator of pollution in Ikpoba river, and reported that 57 fish species were identified, belonging to 39 Genera and 23 families. Fortysix (46) species were from the upstream section of the river while 35 were from the reservoir. Twenty-four (24) fish species were netted from the Ikpoba slope portion of the river while 32 species were collected from the downstream section of the river. According to Oguzie (1996), the occurrence or absence of fish species in a given location can be influenced by human and ecological factors; hence agricultural land use and urban activities can influence fish species diversity and abundance. Furthermore, changes in water quality caused by civilization and technological development, can affect fish populations and the diversity of fish species in aquatic ecosystems. Both benthic and pelagic species were encountered in this study, as was the case in the study by Fufeyin (1994) for the Ikpoba reservoir. Out of the 15 fish species identified in this study, 2 of them were pelagic, namely E. sexfasciatus and $H$. fasciatus while the other 13 species were benthic. Fufeyin (1994), identified more pelagic species (17) than benthic species (12). This variation may have been influenced by factors such as the type of fishing gear used, the time of capture, duration of capture and prevailing ecological conditions. The diversity indices revealed that there were more fishes in terms of general abundance at the Midpoint station and that there was a more even spread and distribution of fish species at the same station. This finding is an indication that the fish species may be more adapted to the ecological conditions at this station. Species-wise, the Ekiuwa station was the richest while the commonest species were found at the Okhoro station. This finding may be attributed to the variations in the water quality and the abundance of specific fish prey at the respective stations which may have accounted for the variation. S. clarias is an omnivorous bottom feeder that feeds on detritus, insect larvae, nymhs, mud and filamentous algae while $H$. fasciatus feeds on young fish especially those of Tilapia and Alestes species. Its diet consists of algae, mosquito larvae, coleopteran nymphs and cray fish. M. psittacus is a bottom feeder that feeds on insect larvae, insects, algae, worms and detritus. The aforementioned dominant and otophysan fish species in this study are commonly utilized by man for food in Nigeria (Idodo-Umeh, 2003). Eleven (11) fish species identified in this study were rare according to the abundance score rating. They are C. nigrodigitatus, M. macrophthalmus, P. afer, X.nigri, S. eupterus, C. taeniatus, M. electricus, C. gariepinus, G. abadii, S. filamentosus and E. sexfasciatus. Of these species, C. gariepinus and C. nigrodigitatus have been reported to be popular aquaculture species in Nigeria (Technical Centre for Agricultural and Rural Co-operation, 2001). The rareness of these fish species could be attributed to a destabilization, disruption and 
modification of the natural habitat of these species following the recent dredging of the Ikpoba river by the authorities of the Ikpoba River Basin Development Committee under the auspicies of the Edo State Government. It has been recognised that anthropogenic activities such as dam constructions, sand filling and the introduction of pollutants from homes and industries can lead to the loss of catchments, habitat degradation and destruction (Ibim and Igbani, 2013). The potential fish yield index was low ranging from 17.7 in the dry months to 23.13 in the wet months. These figures are in league with the low potential fish yield value of 19.52 recorded by Abohweyere (1990) for the Kigera reservoir in New Bussa, Nigeria. It is pertinent to note that with an increase in total dissolved solids which invariably reflects an increase in nutrient content in water, a proportional increase in potential fish yield is expected. Rivers would usually have higher potential fish yields compared to impoundments as they provide a more natural haven for fish with an abundance of natural fish prey and natural spawning grounds (Baijot et al., 1997).

\section{CONCLUSION}

The study presented the fish species composition, their diversity and the potential fish yield of the Ikpoba reservoir in Benin City, Nigeria. The individual composition of the identified fish species varied with three dominant fish species and eleven rare species. The Condition factors for the fish species indicated that these fish species were generally well conditioned in the reservoir while the potential fish yield of the reservoir was low. The study gave a clear insight into the dynamics of the fish species composition in the reservoir which showed a decline in species diversity compared to some previous studies on the Ikpoba river ecosystem. There is thus the need to continuously monitor the Ikpoba reservoir with a view to ensuring that fish species composition and diversity do not reach critical limits in order to promote a more sustainable aquatic ecosystem.

\section{ACKNOWLEDGEMENT}

The immense contribution of the Edo state Urban Water Board, Benin City, Nigeria, is gratefully acknowledged for the provision of technical data on the reservoir.

\section{REFERENCES}

Abdullah, A.Y. (2011). Fisheries Society of Nigeria (FISON) President's memo to National Fisheries Development Committee. $8^{\text {th }}$ March, 2011, Royalton Hotel, Abuja, Nigeria.

Abohweyere, P.O. (1990). Study of limnological parameters and potential fish yield in Kigera reservoir (Extensive system) in Kainji, New Bussa, Nigeria. Journal of Aquatic Sciences, 5: 53- 58.

Adesulu, E. A. \& Sydenham, D. H. J. (2007). The freshwater fishes and fisheries of Nigeria. Mcmillan Nigeria Limited, Ibadan, Nigeria. 397 pp.

Ademoroti, C.M.A. (1996). Environmental Chemistry and toxicology Foludex press Ltd, Ibadan, Nigeria. 215pp.

American Public Health Association (1998). Standard methods for the examination of water and waste waters. 20th Edition. American Public Health Association/ American Water Works Association/Water Environment Federation.

Ames, G., Clucas, I. \& Paul, S. S. (1991). Post-Harvest losses of fish in the tropics. Natural Resources Institute, British Overseas Development Administration. 23 pp.

Asuen, G.O \& Oronsaye, W.L. (1990). Some sedimentological characterization of Ikpoba river in southern Nigeria. Nigerian Journal of Applied Science, 8:29-46. 
Baijot, E., Moreau, J. \& Bouda, S.(1997). Hydrobiological Aspects of Fisheries in Small Reservoirs in the Sahel Region. Technical Centre for Agricultural and Rural Cooperation (ACP-EU), Netherlands, 238 pp.

Chapman, D. (1996). Water Quality Assessments: A guide to use of biota, sediments and water in environmental monitoring. Second Edition. UNESCO/WHO/UNEP. 609 pp.

Choo, P. S. and Williams, M. J. (2003). Fisheries production in Asia: Its role in food security and nutrition. World Fish Center Quarterly, 26 (2): 11-16.

Fufeyin, T. P. (1994). Heavy Metal Concentration in water, Sediment and Fish species of Ikpoba Reservoir, Benin City, Nigeria. Ph.D Thesis, Department of Zoology, University of Benin. Nigeria. 167pp.

Fufeyin, T.P. (1998). Heavy metals in some dominant fish of Ikpoba reservoir in Benin City. Nigerian Environmental Review. 2:61-69.

Holden, M. \& Reed, W. (1972). West African freshwater fish. West African nature handbooks. Longman Group Limited, London. 68 pp.

Horne, A. J. and Goldman, C. R. (1994). Limnology. Second Edition. McGraw-Hill publishers, New York. 564 pp.

Ibim, A. T. \& Igbani, F. (2013). Fish species composition, diversity and abundance in the Lower New Calabar river, Rivers state, Nigeria. In: Conference proceedings of the Nigerian Tropical Biology Association (eds: Olajuyigbe, S. O., Coker, O. M. and Olaleru, F.) $3^{\text {rd }}$ to $4^{\text {th }}$ September, 2013, University of Lagos, Nigeria. pp. 88-92.

Idodo-Umeh, G. (2003). Freshwater fishes of Nigeria (Taxonomy, Ecological notes, Diet and Utilization). Idodo-Umeh publishers, Benin City, Nigeria. 232 pp.

Khan, A. S., Mikkola, H. \& Brummett, R. (2004). Feasibility of Fisheries Co-management in Africa. World Fish Center Quarterly, 27(1 \& 2): 60-64.

Nikolsky, G.V. (1963). The Ecology of Fish. Academic Press, London. 352 pp.

Ogbeibu, A.E. \& Ezeunara, P.U. (2002). Ecological impact of brewery effluents in the Ikpoba river using the fish communities as bioindicators. Journal of Aquatic Science, 17 (1) 35 -44 .

Oguzie, F. A. (1996). Heavy Metals in Fish, Water and effluent of the lower Ikpoba River, Benin City Ph.D. Thesis, Department of Zoology, University of Benin, Benin City. 152 pp.

Oguzie, F.A. (1999). The seasonal food habits of Oreochromis niloticus (Osteichthys: Siluriformes) in the Ikpoba resevoir, Benin City. Nigeria. Journal of Aquatic Science, 14:33-36.

Olaosebikan, B. D. \& Raji, A. (1998). Field guide to Nigerian freshwater fishes. Federal College of Freshwater fisheries Technology, New Bussa, Nigeria. 106 pp.

Orji, R. C. A. \& Onyejiaka, O. (1990). Preliminary investigation of fish species potentials of the Imo river in Nigeria. Journal of Aquatic Sciences, 5: 83-91.

Tawari-Fufeyin, P. \& Ekaye, S.A. (2007). Fish species diversity as indicator of pollution in Ikpoba river, Benin City, Nigeria. Reviews in Fish Biology and Fisheries, 17(1) 21-30.

Technical Centre for Agricultural and Rural Co-operation (2001). Sustainable agropisciculture systems in Sub-Saharan Africa. CTA, Wageningen, The Netherlands. 27 pp.

Tetsola, E.A.(1988). Distribution and feeding relationships of the fishes of Warri river. Ph.D Thesis, Department of Zoology, University of Benin, Benin City, Nigeria. 240 pp.

Walsh, B. (2011). Environment and fish farming: The end of the line. Time International Magazine, New York, July 18 th 2011 , pp. 29-36.

Wangboje, O. M. (2013). Ecological risk assessment of heavy metals and polycyclic aromatic hydrocarbons in Ikpoba reservoir, Benin City, Nigeria. Ph.D Thesis, Department of Fisheries, University of Benin, Benin City, Nigeria. 407 pp. 